\title{
Emotions of quality: a case study on beer products
}

- Nguyen Quoc Cuong *,a

- Le Minh Tam ${ }^{b}$

- Nguyen Ba Thanh ${ }^{\mathrm{c}}$

- Nguyen Hoang Dzung a

(a) Ho Chi Minh City University of Technology, VNU-HCM, Vietnam

(b) Ho Chi Minh City University of Food Industry, Vietnam

(c) Industrial University of Ho Chi Minh City, Vietnam

*Email: nqcuong@ @cmut.edu.vn, Tel: +84.8.8647256 (Ext. 5696)

(Manuscript Received on September 30 ${ }^{\text {th }}, 2014$; Manuscript Revised December $5^{\text {th }}$, 2014)

\section{ABSTRACT}

Quality assurance is very important for food products manufacturers to survive in the extremely competitive markets. Quality, in a simple context in which solely the intrinsic product attributes are focused on, is widely considered as consumer liking [1].

Very often, to better understand product position for the purpose of consumer satisfaction, consumer liking has been related to sensory attributes in traditional sensory and consumer research. Nevertheless, apart from sensory attributes, the current trends of research have focused on emotions, which have come to play a major role in consumer liking.

Our initial goal was to look for relevant emotions to explain consumer liking on beer products. Precisely, this study aimed to address the two following questions: (1) whether or not emotions could be connected with respect to specific products via sensory attributes, if that is the case, (2) whether products, evoking either positive or negative emotions, would be more or less appreciated by consumers.
Two experiments were performed on 8 commercial beer products. In the first experiment, an emotional profile was created by check-all-that-apply questionnaire. The emotional data was then related to consumer liking data collected from the second experiment in order to obtain the preference mapping.

The results showed that the products evoking positive emotions (e.g., optimism, eager, curiosity, etc.) were highly appreciated by consumers, while the products evoking negative emotions (e.g., loneliness, lost, laziness, rage, etc.) received low appreciation.

These results suggested that product quality (i.e., liking in this context) can be better understood through the prism of emotions, the so-called emotions of quality, which were evoked via sensory attributes. It could help researchers and marketing professionals better understand emotions evoked from their products in the one part, and elucidate to approach firm products to ideal products in the other part.

Keywords: emotion, consumer liking, food quality, sensory attribute, beer 


\section{INTRODUCTION}

In a simple context in which solely the intrinsic product attributes are focused on, quality is widely considered as consumer liking [1]. Quality assurance can be considered the most important tool for product manufacturers. However, it is only useful when the manufacturers can be able to transform the perception of consumer liking into physical product attributes.

Very often, to better understand product position for the purpose of consumer satisfaction, liking has been related to sensory attributes in traditional sensory and consumer research.

However, nowadays, apart from sensory properties, emotions have received increasing attention in sensory and consumer science. The main reason could be that emotion has come to play a major role in consumer liking [2].

The objective of this study was to look for relevant emotions to explain consumer liking for beer products. Two experiments were performed. The first experiment aimed to determine which emotions were associated with specific products via sensory attributes, while the second experiment aimed to relate consumer liking to emotions obtained from the first experiment. This empirical study was performed on the commercial beer products. This choice was based on the importance of beer consumption in Vietnam market.

\section{MATERIALS AND METHODS}

\subsection{Materials}

\subsubsection{Samples}

Eight commercial beer products were chosen in the local Vietnamese supermarkets, as follows: Heineken (hei), Tiger (tig), Sapporo (sap), SanMiguel (san), 333 Premium (b33), Saigon Export (exp), Saigon Special (spe), and Hanoi Beer (hn).
The samples, used in tasting sessions, were collected based on their production date and they were stored for approximately 9 months in controlled-atmosphere cabinets.

The samples (10ml for each) were served at $15^{\circ} \mathrm{C}$, in plastic cups coded with three-digit numbers.

\subsubsection{Assessors}

All assessors were recruited from Ho Chi Minh City University of Technology and Industrial University of Ho Chi Minh City, whose ages range from 18 to 25 . They were volenteers and could be potential users, who drink at least once a month.

\subsection{Methods}

\subsubsection{Check-All-That-Apply (CATA) questionnaire}

Consumers were presented with the beer samples following a typical monadic presentation scheme in a randomized balanced order, along with a check-allthat- apply checklist questionnaire of emotions. They were asked to indicate which emotions were perceived with the sample being evaluated.

In this experiment, eight commercial beer products were presented to 160 consumers. The CATA questionnaire of emotion consists of 53 emotional terms, which has been used in the context of consumer research [3].

\subsubsection{Consumer test}

Using the same set of samples and the presentation scheme, a group of 100 consumers was asked to score their overall liking on a 10-point hedonic scale with 10 as "like extremely" and 1 as "dislike extremely."

\subsection{Data analysis}

2.3.1 CATA questionnaire 
The emotion data was structured in a data table, whose rows were products, columns were emotions terms, and intersections were frequencies (the number of consumers checking each emotion per each product $)^{1}$. Such data table was the so-called contingency table. A Correspondence Analysis (CA) was performed on the contingency table to obtain the emotion profiles.

Remarkably, here we wanted to keep as much as possible the potential emotion terms to obtain the emotion profiles. There exists a possible to obtain the profiles mainly based on the significant emotions (i.e., the emotions significantly differentiated the products). Besides, the Cochran's $\mathrm{Q}$ test and the McNemar test should be used to determine the significance of each emotion term. For more details on the statistical procedure of analyzing CATA data, see Le and Worch [4].

\subsubsection{Consumer test}

In the field of sensory and consumer science, preference mapping technique is often used to relate sensory profile data to individual consumer preference data using statistical regression methods (e.g., principal components regression and partial least squares regression) [5]. The results are graphically presented in a bi-plot map, the so-called preference mapping.

In this paper, preference mapping technique was used in the same manner to relate the emotion profile data to individual consumer liking data [6].

\subsubsection{Software}

All statistical analyses were performed using $\mathrm{R}$ software [7] with the package FactoMineR [8] for performing the CA and Preference Mapping analysis, and package nlme for performing one-way withinsubject ANOVA with post-hoc tests [9].

\section{RESULTS}

\subsection{Emotion profile of products}

Fig. 1 shows the representation of beer products in the first two dimensions of CA. The first and second dimension of the CA accounted for $26.87 \%$ and $22.77 \%$ of the total variance of the data, respectively. In this figure, only the emotions which had the representation quality greater than 0.6 were kept.

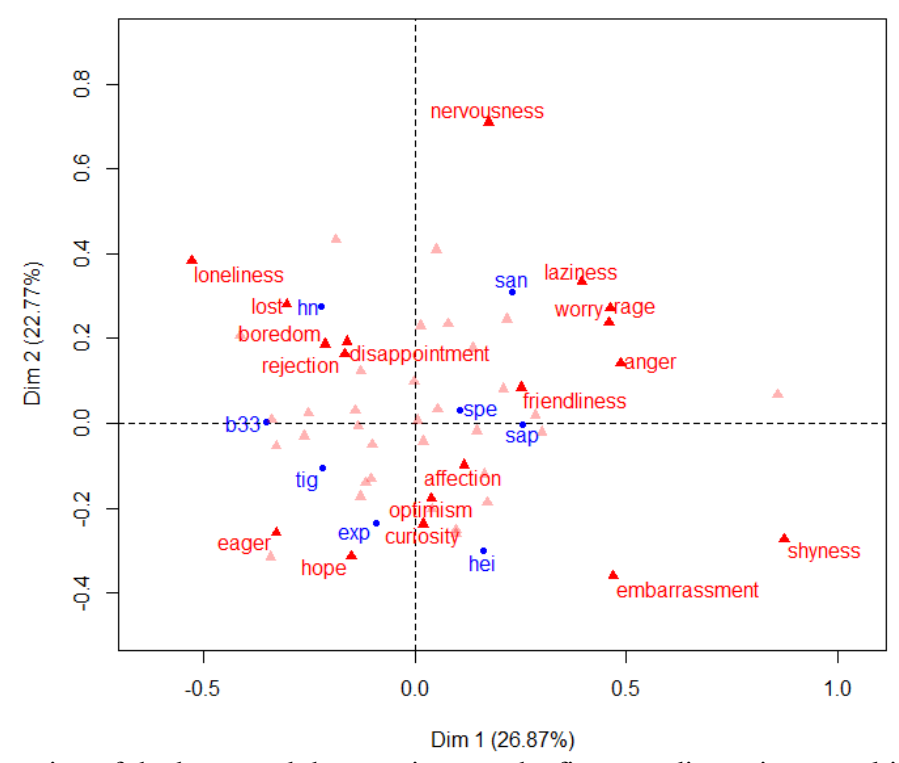

Figure 1. Representation of the beers and the emotions on the first two dimensions resulting from a CA. 
${ }^{1}$ Technically, although the rows and columns of this table have symmetrical role, we proposed the structure as mentioned previously for easily performing the preference mapping technique in the next step.

The positive and negative emotions were opposed mainly on Dim.2. In this dimension, product "san" was perceived by negative emotions such as "laziness", "worry", "rage", and "anger", while product "hn" was perceived as "loneliness", "lost", "boredom", "rejection", and "disappointment". Meanwhile, products "hei", "exp" and "tig" were perceived by positive emotions such as "eager", "hope", "curiosity", “optimism", and "affection".

The results suggested that there existed a structure underlying the relationship between the beer products and emotions evoked, based on their sensory attributes. In other words, each product or each group of products possessed a particular emotion profile. Such emotion profiles will be then linked to the liking of consumers to address the question: whether products perceived by positive (or negative) emotions could be more (or less) appreciated by consumers.

\subsection{Relating consumer liking to emotion profiles}

Before relating the consumer liking to the emotion profiles, a one-way within subject ANOVA was performed on the consumer liking. The significant difference were found for the product effect $(F=6.2$, $D F=7, p<0.01$ ), the results of post-hoc test (i.e., pairwise comparisons) was also presented in Appendix.

Fig. 2 represents the consumer external preference mapping in order to investigate whether these expert criteria related to the quality perceived by consumers. This is a bi-dimensional preference map where quality score was projected into the sensory product space. In this figure, the color ranges from red to blue. The red color represents the area that consumers preferred the most, whereas the blue one represents the area that consumers preferred the least.

It's not surprising that the ideal products were at the top right of the map, where products were notbruised and homogenous. In an opposite direction, the un-ideal products were at the bottom left of the map, where they were bruised and heterogeneous. This showed that the expert criteria could explain the appreciation of quality perceived by consumers. 


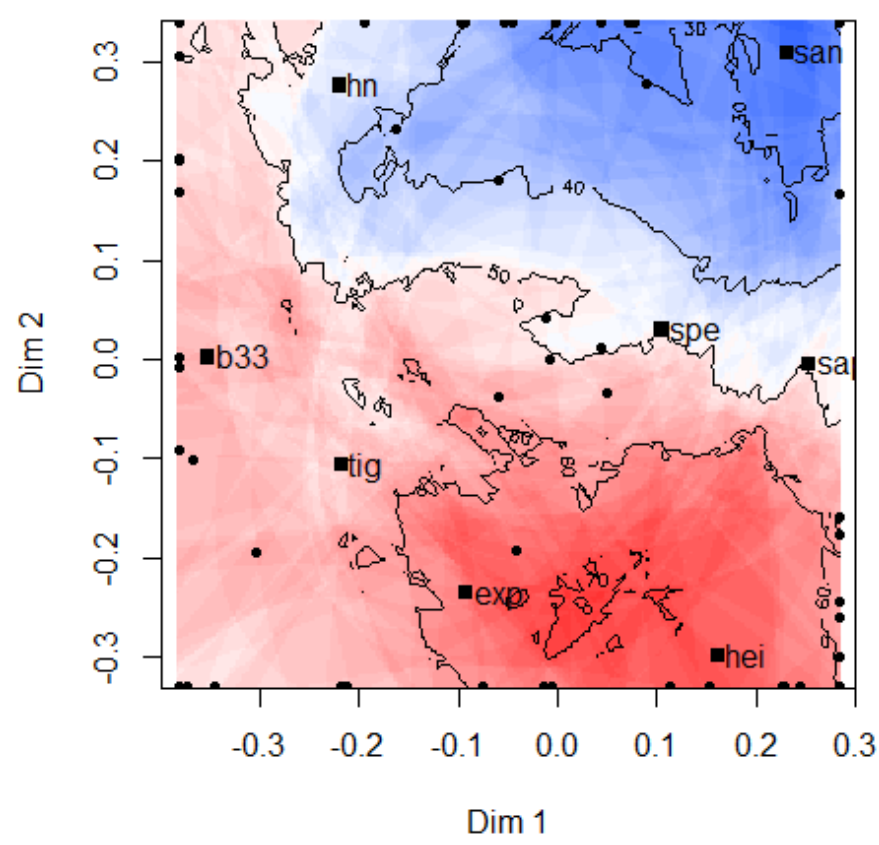

Figure 2. External preference mapping relating the emotion data and the individual consumer preference

\section{CONCLUSIONS}

The results of this study indicated that consumers could perceive and attach emotions to products via their sensory attributes, and interestingly, the emotions evoked (by products) were closely correlated with consumer liking.

Further research should focus on the relationship between liking and emotions which might be evoked in other conditions such as home-use rather than controlled laboratory condition.

\section{ACKNOWLEDGEMENT}

We would like to thank Uyen, T. X. Phan (Sensory Analysis Center, Department of Human Nutrition, Kansas State University, USA) for her insightful comments on the paper, as these comments led us to an improvement of the work. 


\section{APPENDIX}

\section{PAIRWISE COMPARISONS OF BEER PRODUCTS IN CONSUMER OVERALL LIKING}

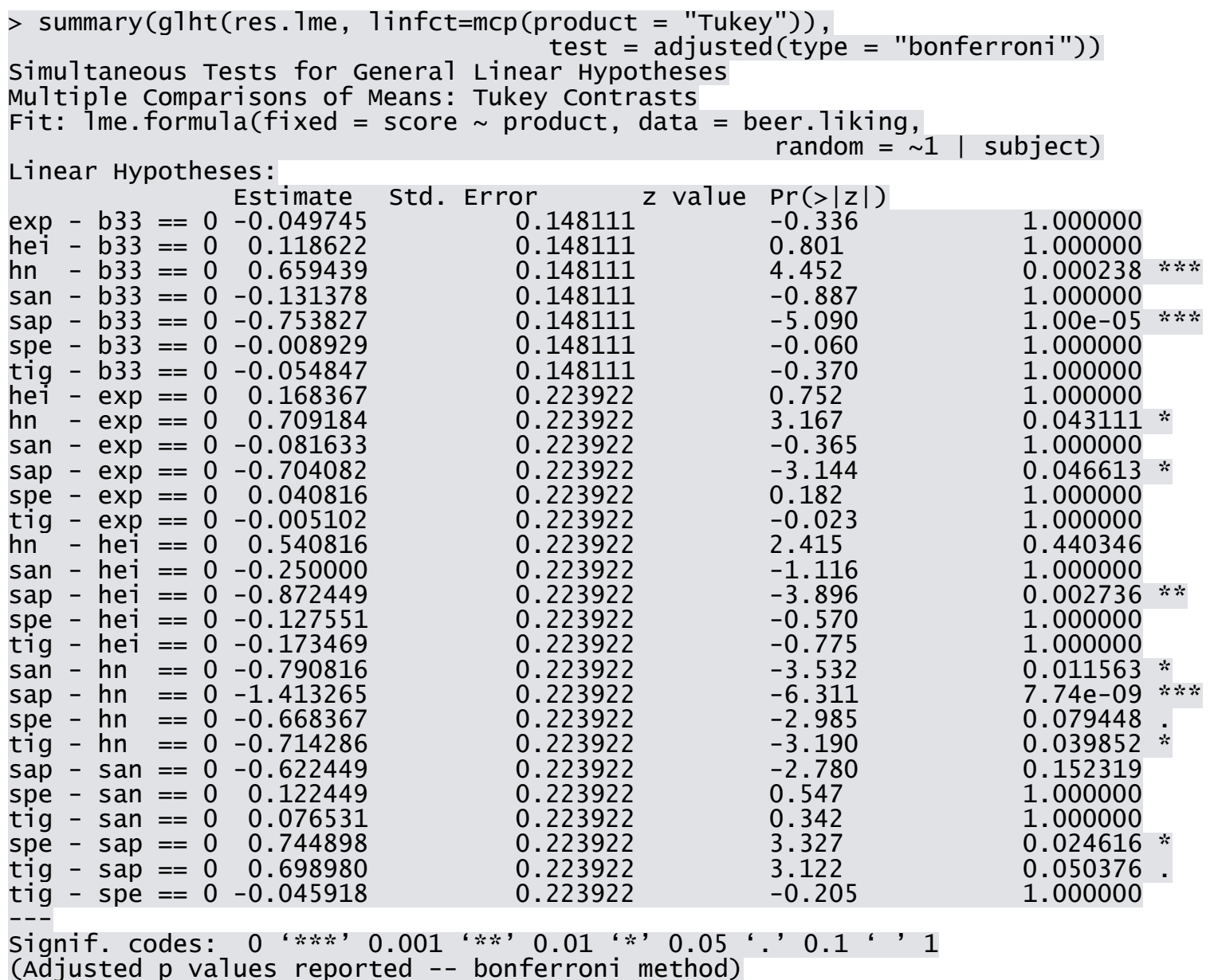




\section{Cảm xúc của chất lượng: một nghiên cứu trên sản phẩm bia}

- Nguyễn Quốc Cường *,a

- Lê Minh Tâm b

- Nguyễn Bá Thanh c

- Nguyễn Hoàng Dũng ${ }^{a}$

(a) Trường Đại học Bách khoa, ĐHQG - HCM, Việt Nam

(b) Trường Đại học Công nghiệp Thực phẩm TpHCM, Việt Nam

(c) Trường Đại học Công nghiệpTpHCM, Việt Nam

*Email: nqcuong@ @cmut.edu.vn, Tel: +84.8.8647256 (Ext. 5696)

\section{TÓM TÁT}

Đảm bảo chất lượng là một vấn đề hết sức quan trọng đối với các nhà sản xuất thực phẩm để tồn tại trong môi trường cạnh tranh. Theo quan điểm của Moskowitz[1], chất lượng của một sản phẩm được xem như là thị hiếu của người tiêu dùng chứ không chỉ là những đặc tính nội tại của nó trong một hoàn cảnh đơn giản.

Để hiểu được sự định vị của sản phẩm theo hướng thỏa mãn nhu cầu người sử dụng, thông thường trong các nghiên cứu cảm quan và người tiêu dùng, thị hiếu được đặt trong mối liên kết với các tính chất cảm quan. Tuy nhiên, ngoài các thuộc tính cảm quan, các xu hướng nghiên cứu gần đây đang chú ý đến cảm xúc như là một yếu tố quan trọng ảnh hưởng đến sự ưa thích của người tiêu dùng.

Mục tiêu của nghiên cứu là đi tìm những trạng thái cảm xúc thích hợp để giải thích cho sự ưa thích của người tiêu dùng đối với sản phẩm bia. Một cách cụ thể, nghiên cứu nhằm vào hai vấn đề sau: (1) cảm xúc có thể liên kết với sản phẩm qua các tính chất cảm quan hay không? (2) một sản phẩm cho dù có tạo nên cảm xúc tích cực hay tiêu cực liệu có thể được ưa thích hay không bởi người tiêu dùng?
Hai thí nghiệm đã được tiến hành trên 8 sản phẩm bia thương mại. Trong thí nghiệm thứ nhất, một profile cảm xúc được thiết lập bằng bảng câu hỏi check-all-that-apply (CATA). Dũr liệu này được kết hợp với thị hiếu của người sử dụng thu thập trong thí nghiệm thứ hai nhằm thu được bản đồ thị hiếu.

Kết quả cho thấy các sản phẩm gợi lên các cảm xúc tích cực (ví dụ: lạc quan, háo hức, tò mò,...) được đánh giá cao bởi người tiêu dùng trong khi các sản phẩm gợi lên các cảm giác tiêu cực (ví dụ: cô độc, mất mát, lười biếng, giận dữ, ...) nhận được đánh giá thấp.

Những kết quả này gợi ý rằng chất lượng sản phẩm (ví dụ, sự ưa thích trong bối cảnh này) có thể được hiểu rõ hơn thông qua lăng kính của những cảm xúc, hay có thể gọi là cảm xúc về chất lượng, được gợi lên qua các thuộc tính cảm quan. Kết quả này một mặt có thể giúp các nhà nghiên cứu và chuyên gia tiếp thị hiểu rõ hơn về cảm xúc gợi lên từ các sản phẩm của họ, và mặt khác làm sáng tỏ cách thức đưa sản phẩm của họ đến sản phẩm lý tưởng. 


\section{REFERENCE}

[1] H. R. Moskowitz, "Food quality: conceptual and sensory aspects," Food Quality and Preference, vol. 6, pp. 157-162, 1995.

[2] M. Ng and J. Hort, "Insights into measuring emotional response in sensory and consumer research," in Rapid Sensory Profiling Techniques: Applications in New Product Development and Consumer Research, J. Delarue, B. Lawlor, and M. Rogeaux, Eds., ed: Woodhead Publishing, 2014, pp. 71-90.

[3] S. Lê, T. M. Lê, and M. Cadoret, "Napping and sorted napping as a sensory profiling technique," in Rapid Sensory Profiling Techniques: Applications in New Product Development and Consumer Research, J. Delarue, B. Lawlor, and M. Rogeaux, Eds., ed: Woodhead Publishing, 2014, pp. 197-213.

[4] S. Le and T. Worch, Analyzing Sensory Data with R: CRC Press, 2014.

[5] P. Schlich and J. McEwan, "Preference Mapping: A Statistical Tool for the Food-
Industry," Sciences Des Aliments, vol. 12, pp. 339-355, 1992.

[6] J. Piggott, "Preference mapping: principles and potential applications to alcoholic beverages," Alcoholic Beverages: Sensory Evaluation and Consumer Research, p. 436, 2011.

[7] T. RCore, "R: A language and environment for statistical computing. $\mathrm{R}$ Foundation for Statistical Computing, Vienna, Austria," ed: ISBN 3-900051-07-0, URL http://www.rproject. org, 2012.

[8] F. Husson, J. Josse, S. Le, and J. Mazet, "FactoMineR: multivariate exploratory data analysis and data mining with $\mathrm{R}, " R$ package version, vol. 1, pp. 102-123, 2013.

[9] J. Pinheiro, D. Bates, S. DebRoy, and D. Sarkar, "Linear and nonlinear mixed effects models," $R$ package version, vol. 3 , p. 57, 2007. 